\title{
PUTTING A PRICE ON NATURE
}

\section{Gretchen Daily knows the value of ecosystems - but can ascribing financial worth to them help to maintain biodiversity? Emma Marris meets an ecosystem-services evangelist.}

W

hen Gretchen Daily was young, she watched acid rain slowly killing the forests around her in Germany's Taunus mountains. As a researcher, she cut her teeth studying extinctions under Paul Ehrlich, an ecologist famed for his predictions of mass starvation. Last month, Daily travelled to Japan in advance of next year's meeting of the Convention on Biodiversity in Nagoya, where the world will hear how spectacularly that treaty has failed to protect the planet's species. All this makes it remarkable that Daily is, eternally, sunny.

Daily's enthusiasm bubbles forth in meeting rooms around the globe as she promotes the 'ecosystem-services' approach to conservation, of which she has become the world's most passionate proponent. Her argument and the argument of a group of like-minded researchers - is that undeveloped nature provides services to human society such as clean water and flood protection that can be valued in financial terms that are large enough to justify protecting it (see 'Ready to serve'). She also believes that this protection can be achieved by installing sufficient financial incentives to make owners want to preserve this bounty.

In 1997, Daily edited an influential book that made a first coherent case for saving the planet with cash (Nature's Services: Societal Dependence on Natural Ecosystems). That same year, a much-discussed paper estimated the total worth of 17 of Earth's major ecosystem services at US\$33 trillion a year (R. Costanza et al. Nature 387, 253-260; 1997). The resultant buzz propelled the idea into the Millennium Ecosystem Assessment report of 2005, which used ecosystem services as a framework to discuss the state of the planet and how to preserve it.

Daily, now working at Stanford University in Palo Alto, California, is gearing up for a major publicity push for the concept in 2010, the International Year of Biodiversity. But this increased attention could also highlight the flaws of the ecosystems-services approach, one of which is its uncertain ability to protect biodiversity: in some cases a biodiverse ecosystem does not necessarily provide services that are more financially valuable. Not that these arguments will stop Daily. "Gretchen is going a zillion miles an hour and she's got this crusade, if you will," says Steve Polasky, an environmental economist at the University of Minnesota,
St Paul. "You often get these crusaders and it is all about them - but with Gretchen it is really about getting ecosystem services on the agenda."

Economists have been working on attaching monetary value to components of natural systems since at least the 1960s, evaluating the cost of damage caused by oil spills, for example. But environmental activists and conservationists didn't pay this work much attention. Many felt that nature should be saved not for it price, but for its own sake.

Daily's conversion happened gradually. Born in the United States, she spent her adolescence in Germany in the midst of early 1980s environmental protests. "It was amazing to see the demonstrations out in the street protesting acid rain and everything connected to it," she says. The experience convinced her of the value of using science and activism to tackle environmental problems.

She did both, working at the Worldwatch Institute, an environmental think tank in Washington DC, as an undergraduate in the mid 1980s and then applying for her graduate studies to work with Ehrlich at Stanford. At a field station in Gothic, Colorado, in the early 1990s, Daily mixed with Ehrlich's influential friends. These included Peter Bing, a rich businessman and then chairman of

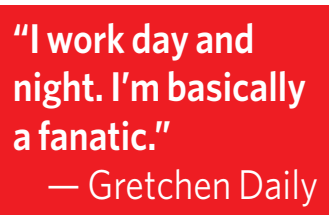

She won financial support from various foundations to prepare, edit and publish Nature's Services and she has hardly looked back since. "There has been tremendous behind-the-scenes progress," says Daily. The concept has been widely embraced by policy-makers. Ecosystemservices projects are now so thick on the ground that one needs a dictionary to keep track of all the acronyms. Among those that Daily salts her conversation with are TEEB (the Economics of Ecosystems and Biodiversity), a European study on how much money the continent might be losing through ecosystem loss, and IPBES, the Intergovernmental Platform on Biodiversity and Ecosystem Services, a proposed scientific advice generator modelled on the Intergovernmental Panel on Climate Change (IPCC).

\section{Seeing solutions}

When Daily is not spreading the word on ecosystem services to scientists, policy-makers and broader audiences, she is pursuing her own studies in places such as Costa Rica and Hawaii. In Hawaii, Daily brought together parties who had long fought over land use - ranchers, native Hawaiians and water and power companies - and persuaded them to write a report, now under review, to the state legislature that recommended reforesting areas of ranchland. Daily got them all to sign up to the same recommendations in the board at Stanford, who "knocked some sense into me" on day-long hikes, says Daily, encouraging her to talk with business people in their language - economics - rather than see them as the enemy. She also met Tim Wirth, who was then one of Colorado's senators and an early advocate of cap-and-trade approaches to combating pollution.

Daily became convinced that such incentive schemes were the way to save the environment.

\section{Ready to serve}

A selection of nature's 'services':

Provisioning: timber, fish, wild game, fruit and fungus, even moss and foliage for floral arrangements.

Regulating: water filtration and capture, flood protection, carbon sequestration.

Cultural: recreation, education, aesthetic and spiritual contemplation. part by focusing on their common concerns about land being converted to be used for high-end homes. Under the new proposal, the ranchers would be paid for reforesting, the native Hawaiians would have access to the forest and the trees would retain rainwater and keep salination of the drinking water supply at bay. "It was really stunningly easy to get people together in dialogue," she says. Long-time collaborator Peter Kareiva, chief scientist of the Nature Conservancy in Seattle, Washington, says of Daily that "people around her are energized. She's built relationships. She just has that personality. She sees a solution."

Daily focuses much of her energy on the Natural Capital Project, a joint effort she brokered between Stanford, the conservation group WWF and the Nature Conservancy. The project, which she co-directs, is developing a software system to help people weigh up the value of land in terms of ecosystem services, 


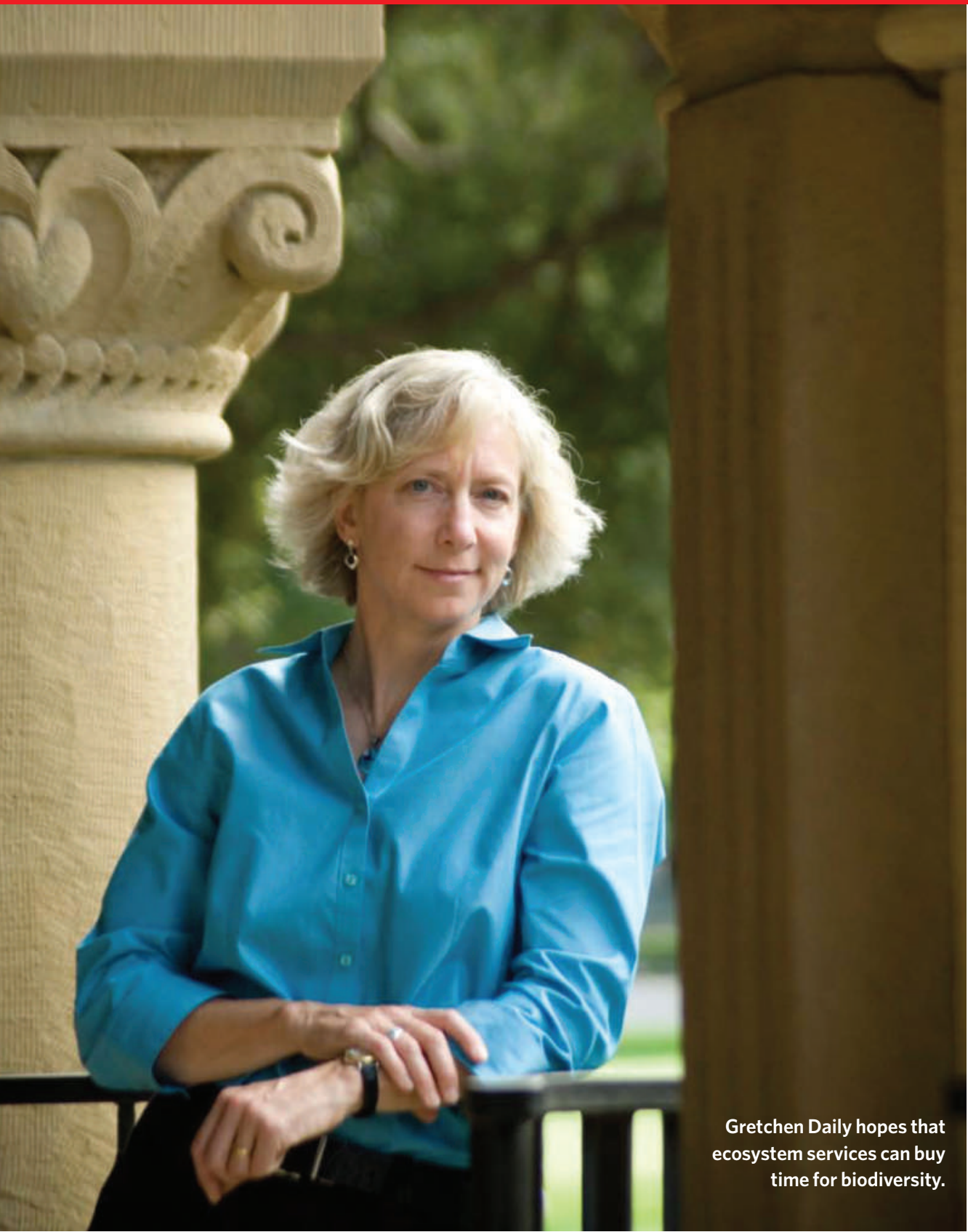

alongside its value for building houses or other development. Maps of an area are layered with information - much of which can be displayed in dollars - such as which parts of the landscape are best for filtering water, where the realestate is most valuable, where the most carbon can be stored and where the biodiversity is highest. Such maps could help governmental organizations evaluate, for example, the cost of building on land that provides free water filtration if the development would then require the construction of a costly water plant. "We can bring about this transformation if we supply tools that make it easy for decision-makers to compare alternative scenarios," she says.

Over the past few years, the maps have been used by officials in China's upper Yangtze River basin to help plan urban and agricultural expansion and dam construction. "I don't earn that much money, but I am laying down my life for all this," Daily says. "I work day and night. I am basically a fanatic."
The idea of ecosystem services has its critics. John Echeverria, an environmental lawyer at Vermont Law School in South Royalton, says that paying landowners not to damage the environment sets up an expectation of reward for refraining from bad behaviour, and a financial obligation for future taxpayers. "The implicit message of agreeing to pay is that they should be entitled to proceed to destroy nature," says Echeverria. Instead, he suggests, landowners should in general be expected to do the right thing and be punished when they don't - the model enforced by the US Endangered Species Act and equivalent legislation in other countries.

Daily contends that the Endangered Species Act and similar laws are failures because their restrictions and penalties have angered many landowners. They also create an incentive for landowners to remove any endangered species from their land before the authorities find out about them. This approach has "led to these past decades of lose-lose battles on the environment", she says.

Richard Carson, an economist at the University of California, San Diego, is a fan of Daily's work, but he says that her pitch tends to focus on the easy cases. "If there is a problem, it is that she has created the impression in people that if you just think about these things in the right way, everyone is going to come out ahead." Daily agrees that she is going after the win-win situations, and says it is because there are still so many easy gains to be made. But eventually, she knows, there will be some tough decisions. If a fish species is close to extinction, it may be necessary to completely close the fishery for some years to ensure that the service (provision of fish) is maintained in the future; and it is difficult to make that decision a 'win' for fishermen.

\section{Rationale for destruction?}

There is another fundamental limitation to the ecosystem-services framework: some services provided by an ecosystem are simply not considered valuable enough to warrant protecting. Biodiversity is particularly problematic. In some cases, a monotonous plain of non-native grass delivers better and cheaper ecosystem services, measured in water filtration, carbon sequestration and flood protection, than a diverse marsh. Attaching explicit values to things can provide a rational basis for ignoring them.

Nevertheless, Daily says, the ecosystemservices approach can save many places with high biodiversity - and at the very least it will give certain ecosystems time until society shows more willingness to protect them for other reasons. "I think it is going to be a long haul for biodiversity for its own sake. For me, ecosystem services is a strategy to buy time as well as getting buy-in." Such sentiment reveals that the ecosystem-services approach is not necessarily that different from conventional environmentalism. Advocates of both viewpoints believe that nature is intrinsically valuable, and they hope to preserve nature by appealing to this belief in others or, where it is absent, by creating it. The difference is that Daily works to convince others by showing them the profitable side of nature first.

Peering through the blur of her hectic work life - the conferences, authoring, media interviews and research - it is clear that Daily isn't just a sunny personality. She is a true optimist. She believes that people can and will save the planet's biodiversity - not just because there is something in it for them, but because, eventually, they will care.

\section{Emma Marris writes for Nature from}

Columbia, Missouri.

See Editorial, page 251, Opinion, page 277, and the biodiversity special at www.nature.com/darwin. 